\title{
Science Parks Connect Entrepreneurs and Public Resources in Emerging Economies
}

\author{
Charles Eesley (Stanford University)
}

\author{
KEYWORDS: Entrepreneurship, Finance, Technology \\ Commercialization, Startups.
}

Unlike the US, most developing countries lack the regulatory and financial infrastructure needed to help promote entrepreneurship. Private resources such as venture capitalists, angel investors and private equity firms often stay away because they worry that their intellectual property won't be protected and their contracts won't be enforced.

That leaves an unlikely front-runner for funding innovation and entrepreneurial enterprise in many developing nations: the government.

This can be challenging for entrepreneurs wanting to break into an emerging market overseas. While government officials may hold the purse, they often lack the expertise to identify entrepreneurs and ventures with promising new technologies. Moreover, even if they could spot these entrepreneurs, government officials typically don't have the technical and business skills needed to help such entrepreneurs succeed. For this reason, many emerging economy governments defer to "institutional intermediaries" such as science parks to evaluate and train entrepreneurs and to help determine which ventures merit receiving public funds.

In a 2016 study, we looked at how science parks provided two critical supports to entrepreneurs in developing nations: capability-building and certification. Science parks build capability because they put technical and business training within easy reach of the entrepreneurs who settle there. Typically, in such settings, there is an application process to gain acceptance into the science park. Thus, they provide certification because being vetted and then selected into a science park validates that a company is "the real deal" and confers both quality and status or prestige. This shows how regulation can confer a "halo of legitimacy" on unknown products that make it through the gauntlet. ${ }^{[1]}$

\begin{abstract}
Our research centered on the question of "exactly what types of entrepreneurs benefit from these science park offerings to secure funding?" To help understand which critical elements are needed for prospective entrepreneurs to succeed in an emerging economy ecosystem, we studied one such country that is particularly important given its size: China. However, our results can be generalized to other emerging economies.
\end{abstract}

We undertook an in-depth field study of 139 science and non-science park ventures in Beijing's Haidian district, then did extensive interviews of science park officials, government officials, entrepreneurs and VCs. Finally, we supplemented this analysis with a second exhaustive study using nationwide archival data.

Our analysis led us to identify two factors, context relevance and skill adequacy, to help answer this question. Context relevance pertains to the notion that if abilities and skills are acquired in the same context that they are to be applied in, they have high context relevance. Put another way, if skill and knowledge are acquired in the same locale they will be used, they can be considered to be of high context relevance. Conversely, if skills and training are learned overseas but brought back to be used locally, it is of low context relevance. Skills adequacy refers to the level of business and/or technical experience that the entrepreneur possesses. An entrepreneur who has strong technical skills but weak business skills has low skill adequacy, resulting in a lower chance of entrepreneurial success.

Three main entrepreneurial groups are most likely to secure government funding. The first are extremely wellconnected and can bypass the science park route altogether and go directly to government officials themselves to obtain funding. The second are high skill adequacy but low context relevance "returnees:" 
entrepreneurs who obtained a substantial amount of business and technical experience overseas but are not locally known. This group benefits from being in a science park because they get the certification pedigree that allows the government to feel comfortable in funding them because the science park has accredited them.

The third group is low skill adequacy but high context relevance "local elites:" entrepreneurs who are locally known and may have high technical skills from a prestigious academic setting such as Beijing University but have little business experience. This group benefits from the capability-building that a science park offers because it will help them supplement their technical expertise with business and management training. They then become good candidates for government funding. The fourth group, low context relevance and low skills adequacy, are very unlikely to secure public funding.

In summary, governments in emerging countries often use intermediaries such as science parks to guide them in funding innovation and entrepreneurship. The entrepreneurial winners in obtaining governmentprovided public resources are those individuals who bring to the country a high degree of overseas technical and business experience and can leverage the pedigree that being in a science park conveys. The other successful entrepreneurs in gaining public funding are the locally well-known and highly technically trained individuals who can gain valuable business skills at these science parks.

\section{The Takeaway}

- If you are a "returnee" entrepreneur struggling to raise funding in a developing country, consider joining a science park, accelerator or similar program to establish your legitimacy and credibility with subsequent investors.

- If you are an engineer turned entrepreneur, consider joining a science park, accelerator or other similar program, but look for especially for programs that offer good coaching and mentorship in the business or managementrelated skills your team may lack.

- If you have strong government ties already, you may not benefit as much from science park or accelerator programs, so you may skip this stage and focus more directly on fundraising from more traditional sources and building your business.

- Today's early-stage entrepreneurs now have access to an increasing number of government, university and private sector programs. Think carefully about your background and that of your team, your strengths and your limitations and seek out resources and programs that are complementary to your skillsets and experience.

\section{References}

Armanios, D.E., Eesley, C.E., Li, J. and Eisenhardt, K.M., 2016. How entrepreneurs leverage institutional intermediaries in emerging economies to acquire public resources. Strategic Management Journal.

Acknowledgements: We thank JC Liang for excellent research assistance in crafting this work.

[1] https://eiexchange.com/content/27-meet-your-newmarketing-team-the-regulators

Additional Search Terms: starting a business overseas, how to do business in China, doing business in third world countries, international businesses 